\title{
HOUSING PRICE CYCLES IN POLAND - THE CASE OF 18 PROVINCIAL CAPITAL CITIES IN 2000-2020
}

\author{
Radoslaw TROJANEK (D)* \\ Department of Microeconomics, Poznan University of Economics and Business, Poznan, Poland
}

Received 15 December 2020; accepted 22 March 2021

\begin{abstract}
Using a unique dataset of 4,5 million offers, the housing cycles in 18 Polish provincial capitals were identified between 2000 and 2020 before and after the financial crisis. Differences in the course of the cycles depending on spatial diversity are presented, as well as differences in the strength of decreases and increases in individual phases. The examined housing markets in Poland have experienced significant variability in the extent of their cycles. One complete cycle was found in each of the analysed cities. Its average duration was approximately 12 years. In this cycle, residential prices (in real terms) increased by $88 \%$ on average, in the upward phase by $158 \%$, while in the downward phase, they decreased by $27 \%$ in the cities under study. A correlation was found that implies that the higher the price rises in the upward period, the higher the price correction ensues in the cycle's downward phase. Moreover, the similarity in fluctuations was present in the metropolitan markets in local housing markets, especially before the financial crisis. Apartment prices continued to grow by $2.9 \%$ on average in the real term during the COVID-19 pandemic in 2020.
\end{abstract}

Keywords: housing prices, housing market, housing cycles, COVID-19, Poland.

\section{Introduction}

The residential real estate sector (understood as the housing market and the residential construction market), through various channels, significantly influences the processes taking place across the entire economy (Bauer, 2017). Economists' increasing interest in the period after the outbreak of the last economic crisis in the housing sector and its impact on the economic situation is significant, taking into account the number of publications in this area. Moreover, despite the small share of this sector in GDP creation, it has started to be included in the general equilibrium model (Chatterjee \& Eyigungor, 2015; Funke et al., 2017; Iacoviello, 2005; Iacoviello \& Neri, 2010; Kaplan et al., 2017; Mian \& Sufi, 2011; Piazzesi \& Schneider, 2016). Relationships between residential property prices, residential investments, and residential wealth are essential for the development of individual economies.

In recent decades, the number of people owning apartments has increased significantly due to the liberalisation of the housing credit markets and social and political changes taking place in individual countries (Wind et al., 2017). The importance of the real estate market results from the scale of aggregated expenditures related to housing, as well as their role in household budgets.
Research carried out in various countries suggests close links between price fluctuations in the housing market and the change in individual countries' economic activity (Claessens et al., 2012; Hirata et al., 2012; Liu et al., 2013; Reinhart \& Rogoff, 2008). This is due to the fact that changes in residential property prices affect macroeconomic aggregates by increasing or decreasing the household's ability to indebt themselves. Given the imperfections of the financial market, price changes affect household assets' size and thus the amount of potential collateral for debt, investments or consumption (Abate \& Anselin, 2016).

Rapid fluctuations in residential property prices through various channels may affect countries' macroeconomic situation (Wachter et al., 2014). Numerous studies have confirmed that residential property prices are strongly correlated with consumption as well as with household debt (Aladangady, 2017; Girouard \& Blöndal, 2001; Kaplan et al., 2015; Mian et al., 2013; Zhu et al., 2019). However, the statement on the impact of residential property prices on household consumption through the property effect is not clear (Berger et al., 2017; Buiter, 2008; Campbell \& Cocco, 2007; Sinai \& Souleles, 2005).

*Corresponding author. E-mail: radoslaw.trojanek@ue.poznan.pl

Copyright () 2021 The Author(s). Published by Vilnius Gediminas Technical University

This is an Open Access article distributed under the terms of the Creative Commons Attribution License (https://creativecommons.org/licenses/by/4.0/), which permits unrestricted use, distribution, and reproduction in any medium, provided the original author and source are credited. 
There are important relationships between the credit market and residential property prices. In the recent literature on the subject, more and more attention has been paid to recognising the impact of changes in residential property prices on the behaviour of banks in credit policy (Chakraborty et al., 2014; Chaney et al., 2012; Cuñat et al., 2017; Hazama \& Uesugi, 2015; Loutskina \& Strahan, 2015; Tai, 2016).

The increase in consumption and investments may result from price increases, which may also lead to increased demand for loans (Goodhart \& Hofmann, 2008). The existing relationships between the fluctuations of residential property prices and the cost and availability of loans confirm that in the event of a drop in property prices and a deterioration in the household property balance, credit conditions may change (Ramcharan \& Crowe, 2013).

The direct effect of the fluctuation of residential property prices on economic activity is visible in the size of residential investments. The increase in residential property prices leads to an increase in profitability of such assets; hence, the scale of residential investments depends to a large extent on residential prices (Girouard \& Blöndal, 2001; Zhu, 2003).

Prices of residential properties may also influence the financial situation of local government units. When taxes (or fees) related to real estate are collected depending on their value, price fluctuations are significant (Alm et al., 2011; Alm \& Leguizamon, 2017; Bronshtein, 2017; Doerner \& Ihlanfeldt, 2011; Goodman, 2018; Lutz et al., 2011; Lutz, 2008; Vlaicu \& Whalley, 2011).

Changes in residential property prices may also affect the development of entrepreneurship, the establishment of new companies (Adelino et al., 2015; Balasubramanyan \& Coulson, 2013; Corradin \& Popov, 2015; Hvide \& Møen, 2010 ) and the volume of employment (Fort et al., 2013; Mehrotra \& Sergeyev, 2016; Schmalz et al., 2017).

Fluctuations in residential property prices may affect the course of business cycles in the economy and significantly impact the transmission of monetary policy impulses to the real economy and, in particular circumstances, on the stability of the financial system (de Bandt et al., 2010). However, the research results in many countries are not clear on this issue; it is emphasised that housing investments better describe the housing cycle than apartment prices (Kim \& Chung, 2016; Kydland et al., 2016; Leamer, 2007, 2015).

To sum up, housing price cycles are of great importance for the stability of the real economy. Residential real estate is an essential part of households' assets and the main source of security for lenders. Moreover, mortgage loans often occupy an important position in banks' balance sheet results and are the largest and most popular form of household debt (European Systemic Risk Board, 2016). The residential real estate sector is an essential component of the real economy, being a source of employment, investment and GDP growth. Considering the above, an attempt was made to identify cycles on the residential market in provincial cities in Poland in the years 2000-2020.
In Poland, due to the relatively short period for which stable time series are available, empirical studies of housing cycles and their links to the economy are not numerous (Augustyniak et al., 2010; Łaszek, 2008; Lis, 2015; Trojanek, 2008, 2010b, 2013). In relation to the housing cycles themselves, the research concerned selected cities and shorter time series (Augustyniak et al., 2018; Bełej et al., 2020; Łaszek, 2008; Trojanek, 2010a; Zelazowski, 2019).

\section{Literature review}

In the literature on real estate cycles, there are different ways of defining them. These definitions most often refer directly to concepts related to business cycles in the economy. The basic methods of distinguishing business cycle fluctuations include level cycle (Burns \& Mitchell, 1946), growth cycle (Mintz, 1972) and the deviation cycles (Lucas, 1977). The first method bases the estimation of fluctuations on the absolute values of the selected measure of economic activity level over time. In a cycle of deviations, the basis for determining turning points are maximum or minimum deviations from the trend. In the growth cycle, turning points are determined by the minimum and maximum growth rates.

The real estate market cycle is defined as recurring but irregular fluctuations in the level of global income from all types of real estate, also marked by other real estate market indicators, but with different advance notice or delay to the average of all types of real estate (Key et al., 1994). A similar definition was proposed by Baum (2001), which describes the real estate market cycle as trends in demand, supply, prices and rates of return from real estate to fluctuations around their long-term trends or average values.

In foreign literature, research on housing cycles is conducted at the country level (Bracke, 2013; Chang, 2010, 2020; Igan \& Loungani, 2012), for regions (André et al., 2019; Chowdhury \& Maclennan, 2014) and at the city level (Akimov et al., 2015; Alqaralleh \& Canepa, 2020; Cunningham \& Kolet, 2011; Fan et al., 2019; Li et al., 2020). These tests concern the identification of cycles and their characteristics, synchronisation of cycles or duration dependence.

The fluctuations in housing prices in various countries show that these cycles vary with the duration and amplitude of changes. The heart of the matter lies mainly in the economic and demographic factors and the real estate market structure specific for every country.

Huber et al. (2016) find that housing cycles are on average 11.7 years long with notable dispersions across 18 OECD countries over the period 1970-2013. On average, upturns last longer and display more duration than downturns. The amplitude of upturns is more extensive on average and reveals a much more significant variability than the amplitude of downturns.

Girouard et al. (2005) find the average length of the housing market cycle was about ten years in eighteen OECD countries in 1975-2004. In the increasing phase (around six years), real housing prices increased by $45 \%$. 
The decreasing phase was relatively shorter (around five years approximately), and real housing prices decreased by ca. $25 \%$. Similar results are provided by Bracke (2013) and Drehmann et al. (2012), who find the average duration of 10.5 years housing cycle.

\section{Methodology}

A large number of methods of extracting fluctuations, based on different theoretical premises and using different techniques, makes determining turning points and cycle phases a complex task. Depending on the adopted procedure, the external image of the cycle, the location of turning points and the duration of phases will differ. In the case of analyses concerning residential cycles, the methods borrowed from analyses of business cycles dominate level cycles (Alqaralleh \& Canepa, 2020; André et al., 2019; Bracke, 2013; Girouard et al., 2005), growth cycles (Agnello et al., 2020) and deviation cycles (Akimov et al., 2015; Fan et al., 2019; Gray, 2018; Zelazowski, 2017).

In trend deviations, the essential element is the way the trend is determined, on which the course of the resulting cyclical fluctuations depends. The identification of business cycle oscillations by the method of deviation from the trend raises doubts because of its function's arbitrary choice, which affects the sensitivity of the results obtained depending on the adopted parameters (Canova, 1998). Considering the above, it was decided to identify housing cycles using the level cycle method.

The starting point was the determination of indices based on the geometric average price of $1 \mathrm{~m}^{2}$ of dwellings for provincial cities in the years 2000-2020. There are many methods of building indices of dwelling prices in the literature, indicating the superiority of hedonic and repeat-sales methods over mean or median methods (Bourassa et al., 2008; Case \& Shiller, 1987; Hansen, 2009; Prasad \& Richards, 2008). The method used is a certain simplification of hedonic methods (only the area of apartments is controlled); however, given the purpose of the study and the size of the sample, it should not significantly burden the results obtained. The obtained indices were CPI-adjusted (price level Q1 2000) and smoothed using the ARIMA X-13 method, which allows the removal of seasonal fluctuations and random factors from the time series. The classic concepts of the business cycle assumed the division of the upward and downward phases into subperiods. Burns and Mitchell, for example, distinguished four phases in their definition of the cycle: expansion, recession, stagnation and recovery. Thus, the upward phase consists of periods of revival and expansion, while the downward phase consists of periods of recession and stagnation (Burns \& Mitchell, 1946). Nowadays, due to the deformation of business cycles (prolongation of the expansion phase and shortening of the recession phase), as well as the lack of clear division criteria in most studies, the cycle is divided into two phases: increase and decrease.

The turning points were determined using the algorithm proposed by Harding and Pagan (2002). The dating technique refers to finding a sequence of local maxima and minima that enable the series to be segmented into expansions and contractions. Moreover, it was assumed that each phase of the cycle would last for at least six quarters and that the full cycle would last for at least 12 quarters (Bracke, 2013; Girouard et al., 2005).

The concordance index was used to study the synchronisation of housing cycles at the city level. The index reflects the share of the number of periods in which two series are in the same phase of the cycle. The concordance index can be estimated as follows (Harding \& Pagan, 2002):

$$
C I=n^{-1} \sum_{t=1}^{T}\left\{S_{j t} S_{r t}+\left(1-S_{j t}\right)\left(1-S_{r t}\right)\right\}
$$

where: $C I$ - concordance index; $S_{j t}$ - dummy variable equalling 1 in case of upturn phase and 0 otherwise in $j$ city; $S_{r t}$ - dummy variable equalling 1 in case of upturn phase and 0 otherwise in $r$ city; $n$ - number of quarters.

\section{Data}

In Poland, the indices of apartment prices for provincial cities are published by the National Bank of Poland (NBP) and the Central Statistical Office (CSO). The NBP was the first to start publishing hedonic indices in 2010 (data from Q3 2006) for the largest cities in Poland. The analyses are based on various databases, including the only one built since 2006. The survey of residential and commercial real estate prices, conducted by the NBP since 2013, is a mandatory part of the Public Statistics Statistical Research Programme. Previously published information about the average transaction and offer prices showed some discrepancy comparing with data from local valuers' databases (Czerski et al., 2017; Hill \& Trojanek, 2020; Konawalczuk, 2014).

Average prices of residential units in provincial cities have been published by the Central Statistical Office since 2015. Previous attempts proved unsuccessful due to difficulties with access to data. It was only the dynamic construction of the Real Estate Price and Value Register database that made it possible to overcome this barrier. It should be emphasised that these indicators are based on premises; the cooperative ownership right is omitted.

Taking into account some limitations of NBP and CSO information, the novel and unique dataset on asking house price dynamics was used in this study. The idea of offer prices as a source of information for computing housing price indexes is not new (Pollakowski, 1995). However, there are not many research articles that compare asking and transaction price indexes. Ahmed et al. (2016) examined the housing market in Switzerland in the years 2005-2015 and showed that asking and transaction prices are co-integrated (i.e., both show similar tendencies in the long-term). In the research conducted by Shimizu et al. (2016) based on data from Tokyo in the years 2005-2009, the authors compared the initial asking price, final asking price, contract price, and transaction price. They showed that there are significant differences in the distribution of 
these prices and the distribution of the attributes of properties. The authors concluded that prices/values obtained at different stages of the selling process are comparable only if the qualitative and quantitative characteristics of flats are considered, making them useful for building price indexes. In another study, Anenberg and Laufer (2017) came to interesting conclusions. Using the information on two million offers from the nine largest U.S. cities in the years 2008-2012, the authors showed that the asking price-based index accurately forecasts the Case-Shiller index (based on the repeat sales method and asking prices) with a few-month lead.

Bearing the above in mind, the study used a unique database of more than 4,5 million housing offers in $18^{1}$ provincial capital cities (Figure A1 in Appendix) in Poland in 2000-2020. The earlier data were obtained from archival advertisements (various local periodicals from the whole country, such as regional editions of the newspaper Anonse, Tydzien Nowosci, Kup Dom, Kontakt, Posrednik, Gazeta Lodzka, Gazeta Olsztynska, regional editions of Gazeta Wyborcza's advertising supplements, Kurier Nieruchomosci, Krakowski Rynek Nieruchomosci, and Jarmark), in the form of photocopies, photographs or periodicals themselves, which were then digitally reproduced and arranged in a database. The data from 2008 were collected from advertising portals (gratka.pl / otodom.pl) for scientific purpose several times a quarter.

The archival data needed to be digitalised. The scope of available information varied and depended on the time of publication (adverts from the end of the 20th century often did not include the asking price; instead, they provided information on whether there was a phone in the flat) and the publisher's requirements. The information on the price, location and size of an apartment was the easiest to find; however, other information was also available but to a lesser extent. The scope of information about offers from ad portals was broader. The most important data include the location (district, housing estate and street), asking price, location in the building (floor), type of ownership, floor size, construction technology, parking facilities and standard of completion. Since this information came from different external sources, it was necessary to adapt the datasets to arrange them into a uniform pattern. The key task was to design a homogeneous database with a uniform system of recording variables. The main problem concerned the identification of location, which is the main factor determining the value of a property. As this factor was defined with a different degree of detail, from the general level (city, district, housing estate, street) to the specific location (street with a house number), properties were grouped and assigned to a proper category. Difficulties arose from the following: the same names of streets and housing estates (e.g., Kopernik street

\footnotetext{
1 Poland is divided into 16 provinces. In the case of two provinces, the voivode and marshal offices are located in different cities. That is why the number of examined cities capitals equals 18 .
}

and Kopernik housing estate in Poznan), wrongly defined location (e.g., the location in a city was recorded, while the offer concerned a suburban town), using customary names when referring to the location (e.g., the Kopernik housing estate in Poznan), streets with identical names in different districts of the same city (Warsaw), and imprecise street names (e.g., avenue or street), which made it challenging to identify the location in the district (e.g., in Warsaw, Wilanowska may be an avenue or a street in two different districts).

Bearing that in mind, the database containing information about street names, postal codes, geo-location (the middle of the street; if a street ran through a few districts, the middle of the street in the district was used) and districts (in the absence of an administrative division into streets, I adopted a division into housing estates or geodetic areas) was built. This database was used as a source for the unification of the previously processed information regarding location to avoid inconsistencies caused by an incorrectly recorded name (spelling errors, lack of soft signs), a street assigned to a wrong district, differences in the spelling of the same street (e.g., for compound street names, especially those commemorating famous people, such as Jan Kochanowski, J. Kochanowski, Kochanowski and Kochanowski J.), differences in the notation of prefixes in names (e.g., priest, Rev.).

For the other data describing offers, the issue of unification was not as problematic (e.g., the location in a building was recorded with a Roman or Arabic number). The process of ordering was performed at the level of individual cities, which made it possible to order data more precisely (for location, streets with identical main parts in their names could be assigned to the wrong areas (e.g., Jaroslaw Dabrowski street, Jan Henryk Dabrowski street, Henryk Dabrowski street). The data prepared in this way underwent a process consisting of removing adverts that did not include crucial information (e.g., lack of price or floor size), removing adverts containing contradictory information which showed that they are incorrect (a flat in a standardised concrete-block building with a floor size of $150 \mathrm{sqm}$, or, before 1950, a flat on the 8th floor of a 5 -floor building, etc.), supplementing data based on the information included in the offer (a building from before 1950 could not have been constructed using standardised concrete-block technology) and supplementing data based on knowledge of the local housing market (in the context of Poznan, the typical characteristics of buildings located in a given area or district).

Initially, more than 5,5 million offers were collected in the database (after preliminary cleaning to remove offers without price, surface area or a specified general or specific location) by both ownership and cooperative ownership of the premises. In addition, repeated offers had to be removed as a result: offering the same apartment in subsequent months (e.g., January, February, March), offering by different intermediaries (the same apartment was offered more than once) and offering the same apartment in a given quarter at different prices (the lowest price offer was left in the database). 
Finally, the database contains 4,509,144 offers of apartments in 18 provincial cities in Poland for the years 2000-2020. The exact number of offers in particular cities is presented in Table A1 in the Appendix. Using the collected information, geometric average prices for $1 \mathrm{~m}^{2}$ of the usable floor area of apartments were determined (Figure 1). Based on them, price indices were determined according to the methodology described above.

On average, the prices of apartments in province cities increased in real terms during the analysed period by $120 \%$ (nominally by $253 \%$ ). The highest increase was recorded in the case of Gdansk by $179 \%$ in real terms (by $347 \%$ in nominal terms), while the lowest increase was recorded in real terms by $91 \%$ (by $206 \%$ in nominal terms in Opole). The course of time series of housing price indices in individual cities shows similarities in the direction of changes, while the strength of these changes is already more differentiated. In the analysed period, periods of both price increase and decrease can be observed. In 2000-2002, the price drop was caused mainly by the economic slowdown. Then, between 2003 and 2007, apartment prices increased, which was caused by Poland's joining the E.U. and the economic situation. A particularly sharp increase in prices on the residential market in Poland took place in 2006-2007 (average real growth of $87 \%$ ), which was caused by an increase in demand resulting mainly from the extremely high availability of housing loans (understood as low-interest rates, high LTV index, a favourable way of determining creditworthiness or extension of the loan period). Moreover, the main determinants include good economic situation, decreasing unemployment, growing household income or non-fundamental factors such as media information about the possibility of raising VAT, the last moment to take advantage of the relief or the prevailing belief that housing prices will only rise. Moreover, speculative capital has appeared on the market. On the supply side, one should undoubtedly mention the lack of availability of land with the possibility of development (the effect of changes in legal regulations). The growth was stopped by the global financial crisis, limited availability of housing loans and the economic slowdown. From 2014 (in the case of some cities, sooner or later), apartment prices started to rise again, which was influenced by an increase in demand caused by the economic situation, government programmes supporting the purchase of a first apartment, low-interest rates and the development of the residential rental market (including Airbnb) in Poland. Apartment prices continued to grow by $2.9 \%$ on average in the real term during the COVID-19 pandemic in 2020 (the rise of the prices between Q1 and Q4 of 2020). The growth was not as dynamic as in 2019. In the fourth quarter of 2020, some slowdown symptoms appeared - in the case of six cities, the prices in real term decreased. The reduction in the availability of mortgage loans, the uncertain economic situation, and reduced rental incomes certainly negatively impacted the housing demand. On the other hand, the reduction in bank deposit interest rates turned individual investors' attention to the housing market, which had always been perceived as a good hedge against inflation.

\section{Results}

The indices of real (after adjustment ARIMA X-13) residential prices in provincial cities in Poland in 2000-2020 were used to identify price fluctuations on the residential market. According to the adopted rules, the cycle consists of an upward phase (price increases) and a downward phase (price decreases); however, to avoid apparent cycles, each phase's minimum length must be greater than six quarters. In this way, turning points were determined, which made it possible to separate residential cycles in individual cities. Figure 2 presents the fluctuations in housing prices in provincial capital cities in 2000-2020.

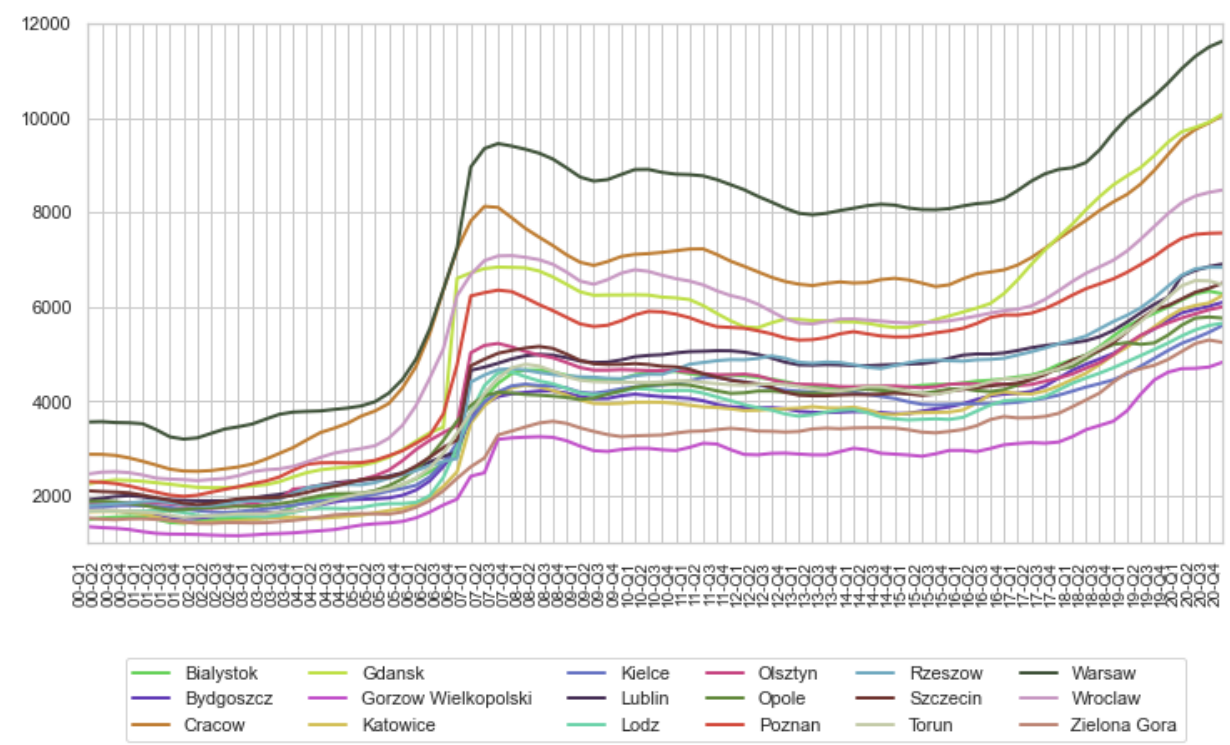

Figure 1. Geometric average prices for $1 \mathrm{~m}^{2}$ in provincial capital cities in Poland in 2000-2020 

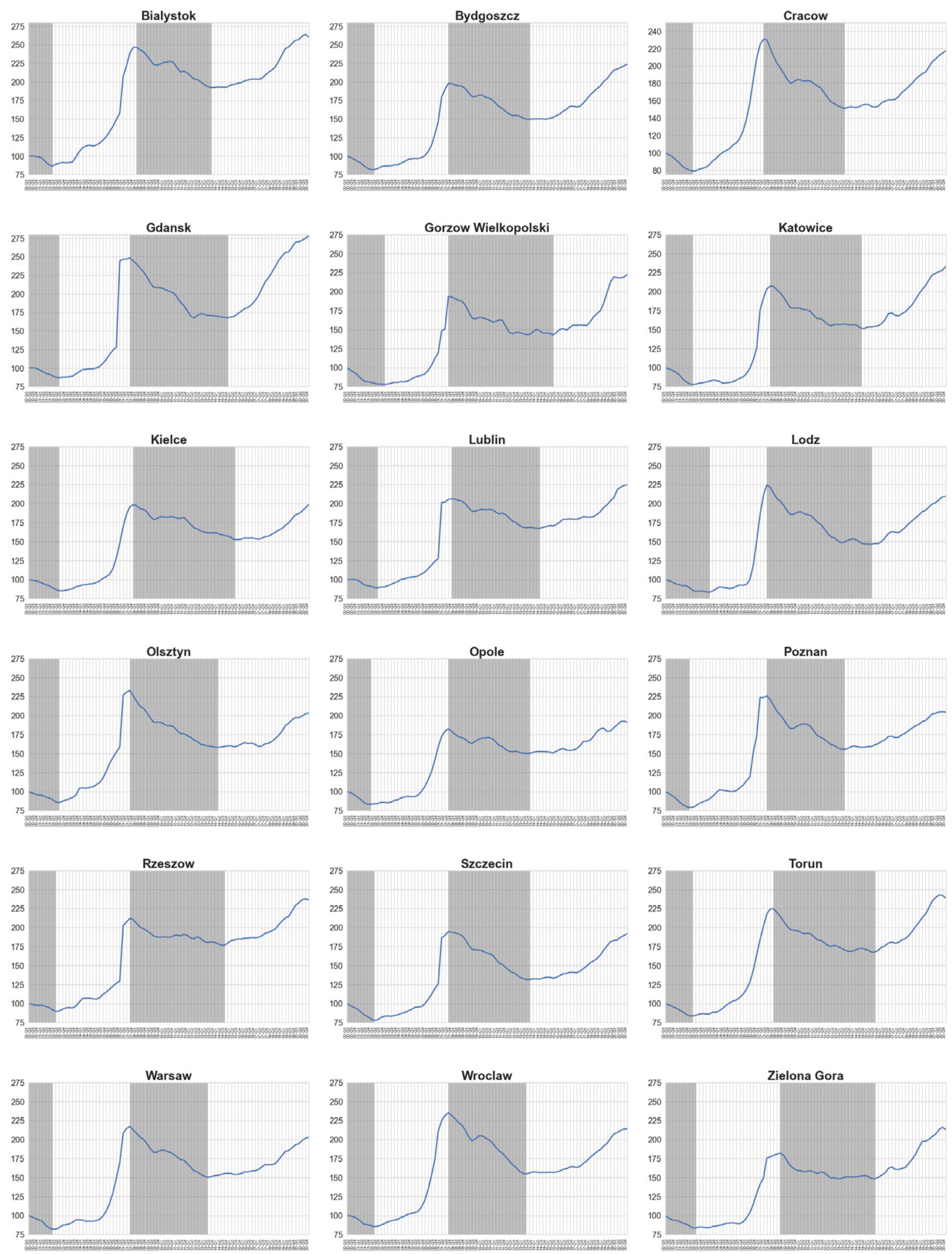

Figure 2. Housing cycles in province cities in Poland in 2000-2020. Grey shading indicates the downturn phase 
Using the price indices presented in the Figure 2, the occurrence of turning points was determined. This made it possible to indicate the observed cycles' structure and separate the upward and downward phases. Then, the length of individual phases was determined (difference in quarters between turning points) as well as percentage changes of prices during their duration (calculations are included in Table 1).
In provincial cities in Poland between 2000 and 2020, four phases of housing cycles could be observed. The beginning of the decline phases, which end occurred in 2002-2003 (depending on the city), cannot be determined, as the price fluctuations of apartments before 2000 are unknown. It can only be stated that the downturn phases lasted for at least 9.6 quarters on average, and apartment prices fell by at least $17 \%$ in real terms. Similarly, it is

Table 1. Morphological features of housing cycles in province cities in Poland in 2000-2020 (source: based on own research)

\begin{tabular}{|c|c|c|c|c|c|c|c|c|}
\hline \multirow[b]{2}{*}{ City } & \multicolumn{4}{|c|}{ Upturn } & \multicolumn{4}{|c|}{ Downturn } \\
\hline & Start & End & Duration & Price increase & Start & End & Duration & Price decrease \\
\hline \multirow[t]{3}{*}{ Bialystok } & & & & & unknown & 2001Q4 & $\min .8$ & $\min .-13 \%$ \\
\hline & 2002Q1 & 2008Q1 & 25 & $185 \%$ & 2008Q2 & 2013Q3 & 22 & $-22 \%$ \\
\hline & 2013Q4 & ongoing & $\min .29$ & $\min .35 \%$ & & & & \\
\hline \multirow[t]{3}{*}{ Bydgoszcz } & & & & & unknown & 2002Q1 & $\min .9$ & $\min .-18 \%$ \\
\hline & 2002Q2 & 2007Q3 & 22 & $142 \%$ & 2007Q4 & 2013Q3 & 24 & $-24 \%$ \\
\hline & 2013Q4 & ongoing & $\min .29$ & $\min .49 \%$ & & & & \\
\hline \multirow[t]{3}{*}{ Cracow } & & & & & unknown & 2002Q1 & $\min .9$ & $\min .-21 \%$ \\
\hline & 2002Q2 & 2007Q2 & 21 & $191 \%$ & 2007Q3 & 2013Q2 & 24 & $-34 \%$ \\
\hline & 2013Q3 & ongoing & $\min .30$ & $\min .44 \%$ & & & & \\
\hline \multirow[t]{3}{*}{ Gdansk } & & & & & unknown & 2002Q2 & min. 10 & $\min .-14 \%$ \\
\hline & 2002Q3 & 2007Q3 & 21 & $186 \%$ & 2007Q4 & 2014Q4 & 29 & $-32 \%$ \\
\hline & 2015Q1 & ongoing & $\min .24$ & $\min .66 \%$ & & & & \\
\hline \multirow{3}{*}{ Gorzow Wlkp. } & & & & & unknown & 2002Q4 & min. 12 & $\min .-22 \%$ \\
\hline & 2003Q1 & 2007Q3 & 19 & $149 \%$ & 2007Q4 & 2015Q2 & 31 & $-25 \%$ \\
\hline & 2015Q3 & ongoing & $\min .22$ & $\min .56 \%$ & & & & \\
\hline \multirow[t]{3}{*}{ Katowice } & & & & & unknown & 2002Q1 & $\min .9$ & $\min .-22 \%$ \\
\hline & 2002Q2 & 2007Q4 & 23 & $166 \%$ & 2008Q1 & 2014Q3 & 27 & $-27 \%$ \\
\hline & 2014Q4 & ongoing & $\min .25$ & $\min .54 \%$ & & & & \\
\hline \multirow[t]{3}{*}{ Kielce } & & & & & unknown & 2002Q2 & $\min .10$ & $\min .-15 \%$ \\
\hline & 2002Q3 & 2007Q4 & 22 & $132 \%$ & 2008Q1 & 2015Q2 & 30 & $-23 \%$ \\
\hline & 2015Q3 & ongoing & $\min .22$ & $\min .30 \%$ & & & & \\
\hline \multirow[t]{3}{*}{ Lublin } & & & & & unknown & 2002Q2 & min. 10 & $\min .-11 \%$ \\
\hline & 2002Q3 & 2007Q4 & 22 & $131 \%$ & 2008Q1 & 2014Q2 & 26 & $-19 \%$ \\
\hline & 2014Q3 & ongoing & $\min .26$ & $\min .34 \%$ & & & & \\
\hline \multirow[t]{3}{*}{ Lodz } & & & & & unknown & 2003Q2 & $\min .14$ & $\min .-17 \%$ \\
\hline & 2003Q3 & 2007Q3 & 17 & $169 \%$ & 2007Q4 & 2015Q2 & 31 & $-32 \%$ \\
\hline & 2015Q3 & ongoing & $\min .22$ & $\min .43 \%$ & & & & \\
\hline \multirow[t]{3}{*}{ Olsztyn } & & & & & unknown & 2002Q2 & $\min .10$ & $\min .-15 \%$ \\
\hline & 2002Q3 & 2007Q3 & 21 & $173 \%$ & 2007Q4 & 2014Q1 & 26 & $-32 \%$ \\
\hline & 2014Q2 & ongoing & $\min .27$ & $\min .29 \%$ & & & & \\
\hline \multirow[t]{3}{*}{ Opole } & & & & & unknown & 2001Q4 & $\min .8$ & $\min .-17 \%$ \\
\hline & 2002Q1 & 2007Q3 & 23 & $119 \%$ & 2007Q4 & 2013Q3 & 24 & $-18 \%$ \\
\hline & 2013Q4 & ongoing & $\min .29$ & $\min .27 \%$ & & & & \\
\hline \multirow[t]{3}{*}{ Poznan } & & & & & unknown & 2001Q4 & $\min .8$ & $\min .-21 \%$ \\
\hline & 2002Q1 & 2007Q3 & 23 & $185 \%$ & 2007Q4 & 2013Q2 & 23 & $-31 \%$ \\
\hline & 2013Q3 & ongoing & $\min .30$ & $\min .31 \%$ & & & & \\
\hline \multirow[t]{3}{*}{ Rzeszow } & & & & & unknown & 2002Q1 & $\min .9$ & $\min .-10 \%$ \\
\hline & 2002Q2 & 2007Q3 & 22 & $136 \%$ & 2007Q4 & 2014Q3 & 28 & $-17 \%$ \\
\hline & 2014Q4 & ongoing & $\min .25$ & $\min .34 \%$ & & & & \\
\hline
\end{tabular}


End of Table 1

\begin{tabular}{|c|c|c|c|c|c|c|c|c|}
\hline \multirow[b]{2}{*}{ City } & \multicolumn{4}{|c|}{ Upturn } & \multicolumn{4}{|c|}{ Downturn } \\
\hline & Start & End & Duration & Price increase & Start & End & Duration & Price decrease \\
\hline \multirow[t]{3}{*}{ Szczecin } & & & & & unknown & 2002Q1 & $\min .9$ & $\min .-22 \%$ \\
\hline & 2002Q2 & 2007Q3 & 22 & $150 \%$ & 2007Q4 & 2013Q3 & 24 & $-32 \%$ \\
\hline & 2013Q4 & ongoing & $\min .29$ & $\min .46 \%$ & & & & \\
\hline \multirow[t]{3}{*}{ Torun } & & & & & unknown & 2002Q1 & $\min .9$ & $\min .-16 \%$ \\
\hline & 2002Q2 & 2008Q1 & 24 & $168 \%$ & 2008Q2 & 2015Q3 & 30 & $-25 \%$ \\
\hline & 2015Q4 & ongoing & $\min .21$ & $\min .42 \%$ & & & & \\
\hline \multirow[t]{3}{*}{ Warsaw } & & & & & unknown & 2002Q1 & $\min .9$ & $\min .-18 \%$ \\
\hline & 2002Q2 & 2007Q3 & 22 & $165 \%$ & 2007Q4 & 2013Q2 & 23 & $-31 \%$ \\
\hline & 2013Q3 & ongoing & $\min .30$ & $\min .35 \%$ & & & & \\
\hline \multirow[t]{3}{*}{ Wroclaw } & & & & & unknown & 2002Q1 & $\min .9$ & $\min .-15 \%$ \\
\hline & 2002Q2 & 2007Q3 & 22 & $175 \%$ & 2007Q4 & 2013Q2 & 23 & $-34 \%$ \\
\hline & 2013Q3 & ongoing & $\min .30$ & $\min .39 \%$ & & & & \\
\hline \multirow[t]{3}{*}{ Zielona Gora } & & & & & unknown & 2002Q2 & $\min .10$ & $\min .-16 \%$ \\
\hline & 2002Q3 & 2008Q3 & 25 & $117 \%$ & 2008Q4 & 2015Q3 & 28 & $-19 \%$ \\
\hline & 2015Q4 & ongoing & $\min .21$ & $\min .44 \%$ & & & & \\
\hline
\end{tabular}

impossible to determine the end of the growth phases started in 2013-2015 (depending on the city); it can only be stated that during the analysis period the growth phases lasted for an average of at least 26.2 quarters and that the minimum average price increase was $41 \%$.

Assuming that the cycle starts with an upward phase, one full cycle could be identified in all analysed cities (from Q1 2002 to Q3 2015 depending on the city). On average, the cycles lasted 48 quarters, with an upward phase of 22 quarters, and was shorter than the downward phase by about four quarters. The longest residential cycle took place in Torun (54 quarters) and the shortest in Cracow, Warsaw and Wroclaw (45 quarters). It should be noted that the upward phase began in most cities in Q1 2002 with a quarter's notice or delay (except for Łódź, where this phase started in Q2 2003) and ended in most cities Q3 2007 (with a quarter notice in Cracow and a maximum of 4 quarters' delay in Zielona Gora). This indicates a high similarity in the course of residential cycles in this period in the analysed cities. The end of this cycle's downward phase was no longer characterised by such consistency (from Q2 2012 to Q3 2015).

In the course of this cycle, residential prices increased on average by $88 \%$, in the upward phase by $158 \%$, while in the downward phase, they decreased by $27 \%$ in the analysed cities (in real terms). The highest price increase was recorded in Białystok by $122 \%$, while the lowest in Szczecin by $69 \%$. In each of the cities, there was a sharp increase in apartment prices (from $117 \%$ in Zielona Gora to $191 \%$ in Cracow in the growth phase). Price drops were not so spectacular any more; on average, prices in the upward phase increased by $7.2 \%$ per quarter, while in the downward phase, they decreased by $1.0 \%$ per quarter on average. Figure 3 shows the relationships between price changes in the individual phases of the cycle.
There is a correlation that indicates that the higher the price increase in the upward phase, the higher the price correction in the downward phase of the cycle. It should be emphasised that price decreases had much lower dynamics than previous increases. The ongoing (in the analysed) growth phase occurring in all cities, on average, already lasts 26.2 quarters, while the average price increase in this period was $41 \%$ in the analysed cities. The price increase is not as dynamic as in the case of the first identified growth phase and was $1.6 \%$ per quarter.

The correlation coefficient and concordance index (Table A2 and Figure A2 in the Appendix, respectively) were used to examine similarities in the course of price cycles. Both measures indicate high similarity in the course of residential cycles in the analysed cities. Correlation coefficients ranged from 0.89 to 1 . The concordance index indicates similar dating of particular turning points. In the

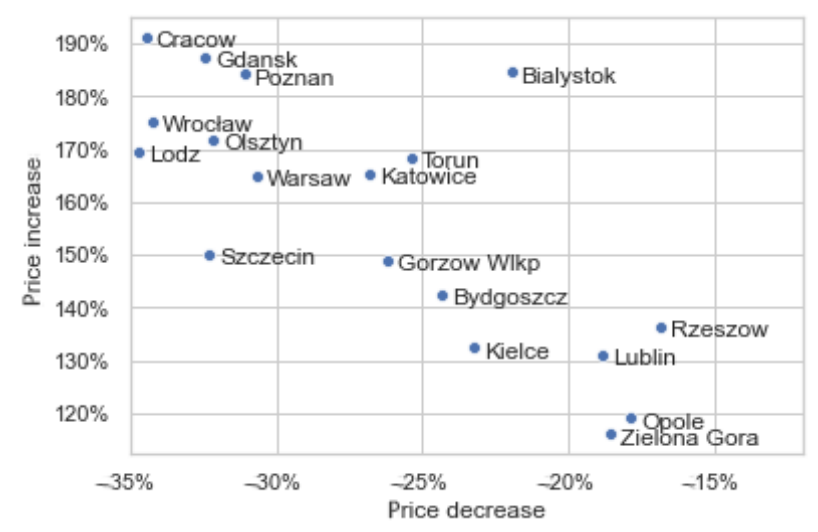

Figure 3. Percentage change of prices during the full housing cycle in province cities in Poland (source: based on own research) 
case of Bydgoszcz and Szczecin, as well as Wroclaw and Warsaw, it assumed the value of 1 , which means that in these cities, the beginning and the end of particular phases of the cycle occurred simultaneously.

\section{Conclusions}

A study of variations in property prices in different countries local markets reveals that these cycles vary not only with length but also with the amplitude of fluctuations. The main goal of the paper was to define housing cycles in the secondary housing market in 2000-2020 in 18 capital cities of provinces in Poland. Using a unique database, it was possible to classify, describe and highlight similarities and differences in housing cycles.

Individual housing markets in Poland have experienced significant variability in the extent of their cycles. One complete cycle was found in each of the analysed cities. Its average duration of which was approximately 12 years, close to the average length of the cycle in other countries.

It should be noted, however, that the housing cycle is most frequently marked by a longer growth phase (Bracke, 2013; Drehmann et al., 2012; Huber et al., 2016). In the case of the analysed cities, the situation was, almost in most cases (Bialystok was the exception - two quarters shorter) the opposite: there were longer declining phases (by about four quarters). During the upward phase of this period, home prices rose sharply, while the downturn was not so severe. There is a correlation that implies that the higher the price rises in the upward period, the higher the price correction ensues in the cycle's downward phase. In the course of this cycle, residential prices (in real terms) increased by $88 \%$ on average, in the upward phase by $158 \%$, while in the downward phase they decreased by $27 \%$ in the analysed cities.

During the COVID-19 pandemic in 2020, apartment prices continued to rise by an average of $2.9 \%$ in real terms (the rise of the prices between Q1 and Q4 of 2020). Some slowdown signs occurred in the fourth quarter of 2020 , with real-term prices declining in the case of six cities and average growth of $0.83 \%$.

The findings of the comparison of co-movements indicate relevant insights, which indicates that the similarity in the course of fluctuations was present in local housing markets, especially before the financial crisis. Methods used in the research allow for considering the degree to which markets spend time in the same phase of a cycle rather than price diffusion or causality, or the magnitude of the relationship (Akimov et al., 2015). These issues, among others, will be the basis of future investigations.

The study is not without limitations, which are mainly related to the source of data. Asking prices usually differ from transactions prices, but the course of indexes based on them should be similar (Trojanek, 2018). More precise results could be produced with hedonic indexes (in case of controlling more apartments' characteristics). However, the study is based on a big dataset, so these limitations should not bias the findings heavily. Moreover, it enabled a longer time horizon to be explored than in the available official statistics.

\section{Funding}

This work was supported by the National Science Centre of Poland under Grant [number 2017/27/B/HS4/01848].

\section{Disclosure statement}

Author declares he does not have any competing financial, professional, or personal interests from other parties.

\section{References}

Abate, G. D., \& Anselin, L. (2016). House price fluctuations and the business cycle dynamics (CREATES Research Paper No. 6). Department of Economics and Business Economics, Aarhus University. https://econ.au.dk/fileadmin/site_files/filer_oekonomi/Working_Papers/CREATES/2016/rp16_06.pdf

Adelino, M., Schoar, A., \& Severino, F. (2015). House prices, collateral, and self-employment. Journal of Financial Economics, 117(2), 288-306. https://doi.org/10.1016/j.jfineco.2015.03.005

Agnello, L., Castro, V., \& Sousa, R. M. (2020). The housing cycle: what role for mortgage market development and housing finance? Journal of Real Estate Finance and Economics, 61, 607-670. https://doi.org/10.1007/s11146-019-09705-z

Ahmed, A., Ardila, D., Sanadgol, D., \& Sornette, D. (2016). Comparing ask and transaction prices in the Swiss housing market (Swiss Finance Insitute Research Paper Series No. 16-80). https://doi.org/10.2139/ssrn.2894404

Akimov, A., Stevenson, S., \& Young, J. (2015). Synchronisation and commonalities in metropolitan housing market cycles. Urban Studies, 52(9), 1665-1682.

https://doi.org/10.1177/0042098014535643

Aladangady, A. (2017). Housing wealth and consumption: evidence from geographically linked microdata. American Economic Review, 107(11), 3415-3446. https://doi.org/10.1257/aer.20150491

Alm, J., Buschman, R. D., \& Sjoquist, D. L. (2011). Rethinking local government reliance on the property tax. Regional Science and Urban Economics, 41(4), 320-331. https://doi.org/10.1016/j.regsciurbeco.2011.03.006

Alm, J., \& Leguizamon, J. S. (2017). The housing crisis, foreclosures, and local tax revenues. Regional Science and Urban Economics, 70, 300-311.

https://doi.org/10.1016/j.regsciurbeco.2017.09.006

Alqaralleh, H., \& Canepa, A. (2020). Housing market cycles in large urban areas. Economic Modelling, 92, 257-267.

https://doi.org/10.1016/j.econmod.2020.01.005

André, C., Gupta, R., \& Muteba Mwamba, J. W. (2019). Are housing price cycles asymmetric? Evidence from the US States and metropolitan areas. International Journal of Strategic Property Management, 23(1), 1-22.

https://doi.org/10.3846/ijspm.2019.6361

Anenberg, E., \& Laufer, S. (2017). A more timely house price index. Review of Economics and Statistics, 99(4), 722-734. https://doi.org/10.1162/REST_a_00634

Augustyniak, H., Gajewski, K., Łaszek, J., Olszewski, K., Pawłowska, M., \& Widłak, M. (2010). Raport o sytuacji na rynku nieruchomości mieszkaniowych i komercyjnych. Warszawa. 
Augustyniak, H., Leszczyński, R., Łaszek, J., Olszewski, K., \& Waszczuk, J. (2018). A simple model of the housing market and the detection of cycles. In J. Łaszek, K. Olszewski, \& R. Sobiecki (Eds.), Recent trends in the real estate market and its analysis. Oficyna wydawnicza SGH.

Balasubramanyan, L., \& Coulson, E. (2013). Do house prices impact business starts? Journal of Housing Economics, 22(1), 36-44. https://doi.org/10.1016/j.jhe.2013.01.001

Bauer, G. H. (2017). International house price cycles, monetary policy and credit. Journal of International Money and Finance, 74, 88-114. https://doi.org/10.1016/j.jimonfin.2017.03.003

Baum, A. (2001). Evidence of cycles in European commercial real estate markets - and some hypotheses. In A global perspective on real estate cycles (pp. 103-115). Springer. https://doi.org/10.1007/978-1-4419-8642-9_6

Bełej, M., Kulesza, S., \& Cellmer, R. (2020). Logical homologies between housting prices dynamics and damped harmonic oscillations. Acta Physica Polonica A, 138(1), 89-95. https://doi.org/10.12693/APhysPolA.138.89

Berger, D., Guerrieri, V., Lorenzoni, G., \& Vavra, J. (2017). House prices and consumer spending. The Review of Economic Studies, 85(3), 1502-1542.

https://doi.org/10.1093/restud/rdx060

Bourassa, S. C., Hoesli, M., Scognamiglio, D. F., \& Sormani, P. (2008). Constant-quality house price indexes for Switzerland. Swiss Journal of Economics and Statistics, 144(4), 561-575. https://doi.org/10.1007/BF03399266

Bracke, P. (2013). How long do housing cycles last? A duration analysis for 19 OECD countries. Journal of Housing Economics, 22(3), 213-230. https://doi.org/10.1016/j.jhe.2013.06.001

Bronshtein, G. (2017). The consequences of the housing boom on local government debt (Discussion Paper No. 17-008). Stanford Institute for Economic Policy Research. https://siepr. stanford.edu/sites/default/files/publications/17-008.pdf

Buiter, W. H. (2008). Housing wealth isn't wealth (NBER Working Paper Series No. 14204). https://doi.org/10.3386/w14204

Burns, A. F., \& Mitchell, W. C. (1946). Measuring business cycles. In NBER books (Vol. 1). National Bureau of Economic Research.

Campbell, J. Y., \& Cocco, J. F. (2007). How do house prices affect consumption? Evidence from micro data. Journal of Monetary Economics, 54(3), 591-621.

https://doi.org/10.1016/j.jmoneco.2005.10.016

Canova, F. (1998). Detrending and business cycle facts. Journal of Monetary Economics, 41(3), 475-512.

https://doi.org/10.1016/S0304-3932(98)00006-3

Case, K. E., \& Shiller, R. J. (1987). Prices of single-family homes since 1970 new index for four cities (Working Paper No. 2393). National Bureau of Economic Research. https://doi.org/10.3386/w2393

Chakraborty, I., Goldstein, I., \& MacKinlay, A. (2014). Do asset price booms have negative real effects? (Jacobs Levy Equity Management Center for Quantitative Financial Research Paper, University of Miami Business School Research Paper No. 3676682).

https://doi.org/10.2139/ssrn.3676682

Chaney, T., Sraer, D., \& Thesmar, D. (2012). The collateral channel: how real estate shocks affect corporate investment. American Economic Review, 102(6), 2381-2409.

https://doi.org/10.1257/aer.102.6.2381

Chang, K. L. (2010). House price dynamics, conditional higherorder moments, and density forecasts. Economic Modelling, 27(5), 1029-1039.

https://doi.org/10.1016/j.econmod.2010.04.007
Chang, K. L. (2020). Are cyclical patterns of international housing markets interdependent? Economic Modelling, 88, 14-24. https://doi.org/10.1016/j.econmod.2019.09.002

Chatterjee, S., \& Eyigungor, B. (2015). A quantitative analysis of the U.S. housing and mortgage markets and the foreclosure crisis. Review of Economic Dynamics, 18(2), 165-184. https://doi.org/10.1016/j.red.2015.02.004

Chowdhury, A., \& Maclennan, D. (2014). Regional house price cycles in the UK, 1978-2012: a Markov switching VAR. Journal of European Real Estate Research, 7(3), 345-366. https://doi.org/10.1108/JERER-02-2014-0014

Claessens, S., Kose, M. A., \& Terrones, M. E. (2012). How do business and financial cycles interact? Journal of International Economics, 87(1), 178-190.

https://doi.org/10.1016/j.jinteco.2011.11.008

Corradin, S., \& Popov, A. (2015). House prices, home equity borrowing, and entrepreneurship. Review of Financial Studies, 28(8), 2399-2428. https://doi.org/10.1093/rfs/hhv020

Cuñat, V., Cvijanović, D., \& Yuan, K. (2017). Within-bank spillovers of real estate shocks. The Review of Corporate Finance Studies, 7(2), 157-193. https://doi.org/10.1093/rcfs/cfy001

Cunningham, R., \& Kolet, I. (2011). Housing market cycles and duration dependence in the United States and Canada. Applied Economics, 43(5), 569-586. https://doi.org/10.1080/00036840802584927

Czerski, J., Głuszak, M., \& Zygmunt, R. (2017). Repeat sales index for residential real estate in Krakow (Working Paper No. 29). Institute of Economic Research.

de Bandt, O., Knetsch, T., Peñalosa, J., \& Zollino, F. (Eds.). (2010). Housing markets in Europe. Springer. https://doi.org/10.1007/978-3-642-15340-2

Doerner, W. M., \& Ihlanfeldt, K. R. (2011). House prices and city revenues. Regional Science and Urban Economics, 41(4), 332-342. https://doi.org/10.1016/j.regsciurbeco.2011.02.004

Drehmann, M., Borio, C., \& Tsatsaronis, K. (2012). Characterising the financial cycle: don't lose sight of the medium term! (BIS Working Papers No. 380). http://ideas.repec.org/p/bis/biswps/380.html

European Systemic Risk Board. (2016). Vulnerabilities in the EU residential real estate sector. https://www.esrb.europa.eu/pub/ pdf/reports/161128_vulnerabilities_eu_residential_real_estate_sector.en.pdf

Fan, Y., Yang, Z., \& Yavas, A. (2019). Understanding real estate price dynamics: the case of housing prices in five major cities of China. Journal of Housing Economics, 43, 37-55. https://doi.org/10.1016/j.jhe.2018.09.003

Fort, T. C., Haltiwanger, J., Jarmin, R. S., \& Miranda, J. (2013). How firms respond to business cycles: the role of firm age and firm size (NBER Working Paper Series No. 19134). https://doi.org/10.3386/w19134

Funke, M., Kirkby, R., \& Mihaylovski, P. (2017). House prices and macroprudential policy in an estimated DSGE model of New Zealand (SEF Working Paper No. 9). https://researcharchive. vuw.ac.nz/xmlui/bitstream/handle/10063/6354/Working\%20 Paper.pdf? sequence $=1$

Girouard, N., \& Blöndal, S. (2001). House prices and economic activity. OECD Publishing.

Girouard, N., Kennedy, M., \& Noord, P. van den. (2005). Recent house price developments: the role of fundamentals. In OECD Economic Outlook (Vol. 2005, pp. 123-154). OECD Publishing. https://doi.org/10.1787/eco_outlook-v2005-2-38-en

Goodhart, C., \& Hofmann, B. (2008). House prices, money, credit, and the macroeconomy. Oxford Review of Economic Policy, 24(1), 180-205. https://doi.org/10.1093/oxrep/grn009 
Goodman, C. B. (2018). House prices and property tax revenues during the boom and bust: evidence from small-area estimates. Growth and Change, 49(4), 636-656.

https://doi.org/10.1111/grow.12261

Gray, D. (2018). An application of two non-parametric techniques to the prices of British dwellings: an examination of cyclicality. Urban Studies, 55(10), 2286-2299. https://doi.org/10.1177/0042098017710381

Hansen, J. (2009). Australian house prices: a comparison of hedonic and repeat-sales measures. Economic Record, 85(269), 132-145. https://doi.org/10.1111/j.1475-4932.2009.00544.x

Harding, D., \& Pagan, A. (2002). Dissecting the cycle: a methodological investigation. Journal of Monetary Economics, 49(2), 365-381. https://doi.org/10.1016/S0304-3932(01)00108-8

Hazama, M., \& Uesugi, I. (2015). Heterogeneous impact of real estate prices on firm investment (Discussion Papers No. 15091). Research Institute of Economy, Trade and Industry.

Hill, R., \& Trojanek, R. (2020). House price indexes for Warsaw: an evaluation of competing methods (Graz Economics Papers - GEP No. 2020-08). https://www.researchgate.net/ publication/340296876_House_Price_Indexes_for_Warsaw_ An_Evaluation_of_Competing_Methods

Hirata, H., Kose, M. A., Otrok, C., \& Terrones, M. E. (2012). Global house price fluctuations: synchronisation and determinants (NBER Working Paper No. 18362). https://doi.org/10.3386/w18362

Huber, S. J., Rott, C., García-Montalvo, J., Caggese, A., Ventura, J., Martin, A., Barnichon, R., Debortoli, D., Davis, M., Taylor, A., Fiedler, A., \& Kajuth, F. (2016). Housing Booms and busts: convergence and divergence in OECD countries. Universitat Pompeu Fabra.

Hvide, H. K., \& Møen, J. (2010). Lean and hungry or fat and content? Entrepreneurs' wealth and start-up performance. Management Science, 56(8), 1242-1258.

https://doi.org/10.1287/mnsc.1100.1177

Iacoviello, M. (2005). House prices, borrowing constraints, and monetary policy in the business cycle. American Economic Review, 95(3), 739-764.

https://doi.org/10.1257/0002828054201477

Iacoviello, M., \& Neri, S. (2010). Housing market spillovers: evidence from an estimated DSGE model. American Economic Journal: Macroeconomics, 2(2), 125-164. https://doi.org/10.1257/mac.2.2.125

Igan, D., \& Loungani, P. (2012). Global housing cycles. IMF Working Papers, 2012(217), 1-56. https://doi.org/10.5089/9781475505672.001

Kaplan, G., Mitman, K., \& Violante, G. (2017). The housing boom and bust: model meets evidence (NBER Working Papers Series No. 23694). https://doi.org/10.3386/w23694

Kaplan, G., Mitman, K., \& Violante, G. (2015). Consumption and house prices in the Great Recession: model meets evidence. https://economicdynamics.org/meetpapers/2015/paper_275.pdf

Key, T., MacGregor, B., Nanthakumaran, N., \& Zarkesh, F. (1994). Understanding the property cycle. Royal Institution of Chartered Surveyors.

Kim, J. R., \& Chung, K. (2016). House prices and business cycles: the case of the UK. International Area Studies Review, 19(2), 131-146. https://doi.org/10.1177/2233865915581432

Konawalczuk, J. (2014). Ocena wybranych baz danych prywatnych i publicznych wykorzystywanych do sporządzania $\mathrm{w}$ latach 2006-2012 raportów rynkowych dotyczących transakcji sprzedaży lokali mieszkalnych - na przykładzie Katowic. Studia Ekonomiczne, 204, 80-95.
Kydland, F. E., Rupert, P., Šustek, R., \& Sustek, R. (2016). Housing dynamics over the business cycle. International Economic Review, 57(4), 1149-1177. https://doi.org/10.1111/iere.12193

Łaszek, J. (2008). Cykliczność rynku nieruchomości mieszkaniowych. In E. Kucharska-Stasiak (Ed.), Cykle rynku nieruchomości a cykle bankowe. Fundacja na Rzecz Kredytu Hipotecznego.

Leamer, E. (2007). Housing is the business cycle (NBER Working Paper No. 13428). https://doi.org/10.3386/w13428

Leamer, E. (2015). Housing really is the business cycle: what survives the lessons of 2008-09? Journal of Money, Credit and Banking, 47, 43-50. https://doi.org/10.1111/jmcb.12189

Li, J., Wei, Y., \& Chiang, Y. H. (2020). Bubbles or cycles? Housing price dynamics in China's major cities. International Journal of Strategic Property Management, 24(2), 90-101.

https://doi.org/10.3846/ijspm.2019.11535

Lis, P. (2015). Cykle mieszkaniowe. Rola rynku i państwa. Wydawnictwo Uniwersytetu Ekonomicznego w Poznaniu.

Liu, Z., Wang, P., \& Zha, T. (2013). Land-price dynamics and macroeconomic fluctuations. Econometrica, 81(3), 11471184. https://doi.org/10.3982/ECTA8994

Loutskina, E., \& Strahan, P. E. (2015). Financial integration, housing, and economic volatility. Journal of Financial Economics, 115(1), 25-41. https://doi.org/10.1016/j.jfineco.2014.09.009

Lucas, R. E. (1977). Understanding business cycles. CarnegieRochester Conference Series on Public Policy, 5, 7-29. https://doi.org/10.1016/0167-2231(77)90002-1

Lutz, B. F. (2008). The connection between house price appreciation and property tax revenues. National Tax Journal, 61(3), 555-572. https://doi.org/10.17310/ntj.2008.3.13

Lutz, B., Molloy, R., \& Shan, H. (2011). The housing crisis and state and local government tax revenue: five channels. Regional Science and Urban Economics, 41(4), 306-319. https://doi.org/10.1016/j.regsciurbeco.2011.03.009

Mehrotra, N., \& Sergeyev, D. (2016). Financial shocks and job flows (CEPR Discussion Papers No. 11677). https://EconPapers.repec.org/RePEc:cpr:ceprdp:11677

Mian, A., Rao, K., \& Sufi, A. (2013). Household balance sheets, consumption, and the ecoomic slump. Quarterly Journal of Economics, 128(4), 1687-1726. https://doi.org/10.1093/qje/qjt020

Mian, A., \& Sufi, A. (2011). House prices, home equity-based borrowing, and the US household leverage crisis. American Economic Review, 101(5), 2132-2156. https://doi.org/10.1257/aer.101.5.2132

Mintz, I. (1972). Dating American growth cycles. In Economic research: retrospect and prospect: Vol. 1. The business cycle today (pp. 39-88). National Bureau of Economic Research, Inc.

Piazzesi, M., \& Schneider, M. (2016). Housing and macroeconomics. Handbook of Macroeconomics, 2, 1547-1640. https://doi.org/10.1016/bs.hesmac.2016.06.003

Pollakowski, H. O. (1995). Data sources for measuring house price changes. Journal of Housing Research, 6(3), 377-387.

Prasad, N., \& Richards, A. (2008). Improving through authors median housing price indexes stratification. Journal of Real Estate Research, 30, 45-72. https://doi.org/10.1080/10835547.2008.12091213

Ramcharan, R., \& Crowe, C. (2013). The impact of house prices on consumer credit: evidence from an internet bank. Journal of Money, Credit and Banking, 45(6), 1085-1115. https://doi.org/10.1111/jmcb.12045

Reinhart, C. M., \& Rogoff, K. S. (2008). This time is different: a panoramic view of eight centuries of financial crises (Working Paper No. 13882). https://doi.org/10.3386/w13882 
Schmalz, M. C., Sraer, D. A., \& Thesmar, D. (2017). Housing collateral and entrepreneurship. Journal of Finance, 72(1), 99-132. https://doi.org/10.1111/jofi.12468

Shimizu, C., Nishimura, K. G., \& Watanabe, T. (2016). House prices at different stages of the buying/selling process. Regional Science and Urban Economics, 59, 37-53. https://doi.org/10.1016/j.regsciurbeco.2016.04.001

Sinai, T., \& Souleles, N. S. (2005). Owner-occupied housing as a hedge against rent risk. Quarterly Journal of Economics, 120(2), 763-789. https://doi.org/10.1162/0033553053970197

Tai, M. (2016). House prices and the allocation of consumer credit (Working Paper). https://scholar.harvard.edu/mingzhu_tai/ publications/house-prices-and-allocation-consumer-credit-0

Trojanek, R. (2008). Wahania cen na rynku mieszkaniowym. Wydawnictwo Akademii Ekonomicznej w Poznaniu.

Trojanek, R. (2010a). Cyclical behaviour of residential markets. Journal of International Studies, 3(1), 28-35. https://doi.org/10.14254/2071-8330.2010/3-1/3

Trojanek, R. (2010b). Dwelling's price fluctuations and the business cycle. Economics and Sociology, 3(2), 67-77. https://doi.org/10.14254/2071-789X.2010/3-2/7

Trojanek, R. (2013). Fluctuations of dwellings' prices in the biggest cities in Poland during 1996-2011. Actual Problems of Economics, 2(1-2), 224-231.

Trojanek, R. (2018). Teoretyczne i metodyczne aspekty wyznaczania indeksów cen na rynku mieszkaniowym. Wydanictwo Uniwersytetu Ekonomicznego w Poznaniu.
Vlaicu, R., \& Whalley, A. (2011). Do housing bubbles generate fiscal bubbles? Public Choice, 149(1-2), 89-108. https://doi.org/10.1007/s11127-011-9830-y

Wachter, S. M., Cho, M., \& Tcha, M. J. (2014). The global financial crisis and housing: a new policy paradigm. Edward Elgar Publishing. https://doi.org/10.4337/9781783472888.00006

Wind, B., Lersch, P., \& Dewilde, C. (2017). The distribution of housing wealth in 16 European countries: accounting for institutional differences. Journal of Housing and the Built Environment, 32(4), 625-647. https://doi.org/10.1007/s10901-016-9540-3

Zelazowski, K. (2017). Housing market cycles in the context of business cycles. Real Estate Management and Valuation, 25(3), 5-14. https://doi.org/10.1515/remav-2017-0017

Zelazowski, K. (2019). Price convergence in the regional housing markets in Poland. Real Estate Management and Valuation, 27(2), 44-52. https://doi.org/10.2478/remav-2019-0014

Zhu, B., Li, L., Downs, D. H., \& Sebastian, S. (2019). New evidence on housing wealth and consumption channels. Journal of Real Estate Finance and Economics, 58, 51-79. https://doi.org/10.1007/s11146-017-9638-8

Zhu, H. (2003). The importance of property markets for monetary policy and financial stability (BIS Working Paper No. 21). http://www.bis.org/publ/bppdf/bispap21c.pdf

\section{Appendix}

Table A1. Number of offers gathered in provincial capital cities in 2000-2020

\begin{tabular}{|c|c|c|c|c|c|c|c|c|c|c|c|c|c|c|c|c|c|c|c|c|c|}
\hline & 2000 & 2001 & 2002 & 2003 & 2004 & 2005 & 2006 & 2007 & 2008 & 2009 & 2010 & 2011 & 2012 & 2013 & 2014 & 2015 & 2016 & 2017 & 2018 & 2019 & 2020 \\
\hline Biatystok & 1067 & 1093 & 1667 & 6014 & 2146 & 3073 & 4553 & 7212 & 10310 & 4209 & 6244 & 5667 & 5714 & 2955 & 5432 & 3085 & 5253 & 4415 & 3764 & 1763 & 1963 \\
\hline Bydgoszcz & 4735 & 4391 & 4841 & 4923 & 5971 & 6158 & 4152 & 7678 & 17715 & 25592 & 30043 & 6913 & 29154 & 28483 & 10306 & 9466 & 9080 & 10069 & 9484 & 7433 & 7245 \\
\hline Cracow & 8564 & 10265 & 13015 & 12026 & 10436 & 14073 & 9755 & 11987 & 26130 & 43203 & 40583 & 29745 & 71814 & 73374 & 27733 & 22491 & 43550 & 30764 & 41032 & 34956 & 54124 \\
\hline Gdansk & 3217 & 1247 & 4976 & 6282 & 4196 & 12402 & 8036 & 9431 & 21785 & 21340 & 20758 & 16310 & 8989 & 10033 & 17585 & 4907 & 12076 & 10483 & 15622 & 14442 & 18612 \\
\hline Gorzow Wlkp. & 1256 & 1843 & 773 & 1390 & 449 & 550 & 597 & 763 & 1020 & 1363 & 1401 & 2125 & 2769 & 2805 & 676 & 682 & 1489 & 764 & 649 & 755 & 814 \\
\hline Katowice & 2166 & 1888 & 1803 & 3198 & 2378 & 4438 & 2534 & 5177 & 13123 & 19134 & 17967 & 10875 & 12102 & 8700 & 5571 & 5584 & 7369 & 6416 & 8656 & 6043 & 11865 \\
\hline Kielce & 1328 & 1406 & 1078 & 3941 & 2794 & 4472 & 3942 & 4754 & 8316 & 7903 & 8482 & 3153 & 4879 & 4858 & 3527 & 1907 & 3503 & 2732 & 4273 & 4993 & 6176 \\
\hline Lublin & 1406 & 1489 & 1532 & 4280 & 3628 & 6749 & 9169 & 10127 & 20736 & 21121 & 15196 & 4885 & 6060 & 10692 & 8161 & 4162 & 5048 & 3956 & 6519 & 4697 & 6612 \\
\hline Lodz & 2587 & 1951 & 686 & 5845 & 1797 & 5596 & 7465 & 11302 & 17556 & 29674 & 21875 & 21150 & 34351 & 31391 & 19240 & 12388 & 15602 & 14258 & 20524 & 17893 & 18247 \\
\hline Olsztyn & 1961 & 5302 & 1633 & 2423 & 2563 & 3037 & 2878 & 3745 & 7597 & 8045 & 6113 & 8704 & 8201 & 4501 & 5218 & 2825 & 3930 & 3199 & 4560 & 4160 & 4847 \\
\hline Opole & 1210 & 790 & 908 & 2247 & 1872 & 1064 & 922 & 1497 & 2188 & 1027 & 2948 & 1966 & 3331 & 3750 & 949 & 794 & 1626 & 1064 & 1202 & 1002 & 1513 \\
\hline Poznan & 6187 & 4935 & 5294 & 7970 & 6851 & 5656 & 6099 & 12000 & 28996 & 39485 & 28155 & 25644 & 40568 & 28900 & 14936 & 10132 & 18865 & 18957 & 20532 & 12028 & 18353 \\
\hline Rzeszow & 971 & 803 & 841 & 1117 & 1466 & 3077 & 3035 & 6533 & 10300 & 9456 & 6752 & 1952 & 1640 & 2100 & 860 & 1011 & 2234 & 1968 & 3364 & 1887 & 3381 \\
\hline Szczecin & 3096 & 1904 & 1020 & 6238 & 6883 & 6854 & 6684 & 13731 & 22726 & 19984 & 17348 & 10847 & 12047 & 7718 & 4605 & 5359 & 7763 & 6929 & 5227 & 4023 & 4790 \\
\hline Torun & 408 & 1157 & 982 & 2551 & 1424 & 1155 & 1983 & 2754 & 9391 & 15554 & 11993 & 10149 & 12747 & 12080 & 12796 & 7221 & 8767 & 7317 & 8679 & 3895 & 2916 \\
\hline Warsaw & 10168 & 12209 & 10775 & 11607 & 19898 & 31144 & 34815 & 37173 & 98790 & 105878 & 72026 & 54994 & 121481 & 100907 & 63527 & 57722 & 102406 & 59712 & 62828 & 87641 & 115612 \\
\hline Wroclaw & 2082 & 2199 & 2607 & 4282 & 2836 & 6939 & 8484 & 8529 & 28407 & 37168 & 41430 & 29758 & 46175 & 29332 & 15088 & 9959 & 30617 & 17344 & 19847 & 23750 & 28233 \\
\hline Zielona Gora & 1848 & 1339 & 1431 & 2644 & 1712 & 787 & 900 & 1212 & 2339 & 2807 & 1552 & 1741 & 3103 & 2229 & 698 & 1351 & 2320 & 1589 & 1222 & 951 & 972 \\
\hline
\end{tabular}


Table A2. Concordance index of housing cycles in provincial capital cities in 2000-2020

\begin{tabular}{|c|c|c|c|c|c|c|c|c|c|c|c|c|c|c|c|c|c|c|}
\hline & 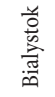 & 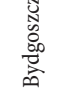 & 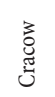 & 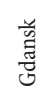 & 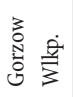 & 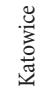 & $\frac{\ddot{U}}{\ddot{\Xi}}$ & $\stackrel{\Xi}{\Xi}$ & ్ㅗㅇ & $\begin{array}{c}\sum_{\substack{N \\
0}}^{E} \\
\frac{n}{0}\end{array}$ & $\begin{array}{l}\frac{y}{0} \\
\stackrel{0}{0}\end{array}$ & $\begin{array}{l}\text { जี } \\
\text { ڤ్ี }\end{array}$ & 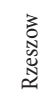 & 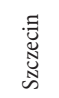 & 志 & $\begin{array}{l}\text { 总 } \\
\text { 䓌 } \\
\text { 点 }\end{array}$ & $\frac{\text { 总 }}{3}$ & 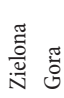 \\
\hline Bialystok & 1.00 & 0.96 & 0.94 & 0.88 & 0.85 & 0.93 & 0.88 & 0.93 & 0.82 & 0.93 & 0.98 & 0.96 & 0.92 & 0.96 & 0.89 & 0.95 & 0.95 & 0.86 \\
\hline Bydgoszcz & 0.96 & 1.00 & 0.98 & 0.92 & 0.88 & 0.94 & 0.89 & 0.94 & 0.86 & 0.96 & 0.99 & 0.98 & 0.95 & 1.00 & 0.88 & 0.99 & 0.99 & 0.85 \\
\hline Cracow & 0.94 & 0.98 & 1.00 & 0.92 & 0.86 & 0.92 & 0.87 & 0.92 & 0.83 & 0.94 & 0.96 & 0.98 & 0.93 & 0.98 & 0.86 & 0.99 & 0.99 & 0.82 \\
\hline Gdansk & 0.88 & 0.92 & 0.92 & 1.00 & 0.94 & 0.95 & 0.95 & 0.95 & 0.92 & 0.95 & 0.90 & 0.89 & 0.96 & 0.92 & 0.92 & 0.90 & 0.90 & 0.90 \\
\hline Gorzow Wlkp. & 0.85 & 0.88 & 0.86 & 0.94 & 1.00 & 0.92 & 0.96 & 0.92 & 0.98 & 0.92 & 0.87 & 0.86 & 0.93 & 0.88 & 0.93 & 0.87 & 0.87 & 0.92 \\
\hline Katowice & 0.93 & 0.94 & 0.92 & 0.95 & 0.92 & 1.00 & 0.95 & 0.98 & 0.89 & 0.95 & 0.93 & 0.92 & 0.99 & 0.94 & 0.94 & 0.93 & 0.93 & 0.90 \\
\hline Kielce & 0.88 & 0.89 & 0.87 & 0.95 & 0.96 & 0.95 & 1.00 & 0.95 & 0.94 & 0.93 & 0.88 & 0.87 & 0.94 & 0.89 & 0.96 & 0.88 & 0.88 & 0.95 \\
\hline Lublin & 0.93 & 0.94 & 0.92 & 0.95 & 0.92 & 0.98 & 0.95 & 1.00 & 0.89 & 0.98 & 0.93 & 0.92 & 0.96 & 0.94 & 0.92 & 0.93 & 0.93 & 0.90 \\
\hline Lodz & 0.82 & 0.86 & 0.83 & 0.92 & 0.98 & 0.89 & 0.94 & 0.89 & 1.00 & 0.89 & 0.85 & 0.83 & 0.90 & 0.86 & 0.90 & 0.85 & 0.85 & 0.89 \\
\hline Olsztyn & 0.93 & 0.96 & 0.94 & 0.95 & 0.92 & 0.95 & 0.93 & 0.98 & 0.89 & 1.00 & 0.95 & 0.94 & 0.96 & 0.96 & 0.89 & 0.95 & 0.95 & 0.88 \\
\hline Opole & 0.98 & 0.99 & 0.96 & 0.90 & 0.87 & 0.93 & 0.88 & 0.93 & 0.85 & 0.95 & 1.00 & 0.99 & 0.94 & 0.99 & 0.87 & 0.98 & 0.98 & 0.83 \\
\hline Poznan & 0.96 & 0.98 & 0.98 & 0.89 & 0.86 & 0.92 & 0.87 & 0.92 & 0.83 & 0.94 & 0.99 & 1.00 & 0.93 & 0.98 & 0.86 & 0.99 & 0.99 & 0.82 \\
\hline Rzeszow & 0.92 & 0.95 & 0.93 & 0.96 & 0.93 & 0.99 & 0.94 & 0.96 & 0.90 & 0.96 & 0.94 & 0.93 & 1.00 & 0.95 & 0.93 & 0.94 & 0.94 & 0.89 \\
\hline Szczecin & 0.96 & 1.00 & 0.98 & 0.92 & 0.88 & 0.94 & 0.89 & 0.94 & 0.86 & 0.96 & 0.99 & 0.98 & 0.95 & 1.00 & 0.88 & 0.99 & 0.99 & 0.85 \\
\hline Torun & 0.89 & 0.88 & 0.86 & 0.92 & 0.93 & 0.94 & 0.96 & 0.92 & 0.90 & 0.89 & 0.87 & 0.86 & 0.93 & 0.88 & 1.00 & 0.87 & 0.87 & 0.96 \\
\hline Warsaw & 0.95 & 0.99 & 0.99 & 0.90 & 0.87 & 0.93 & 0.88 & 0.93 & 0.85 & 0.95 & 0.98 & 0.99 & 0.94 & 0.99 & 0.87 & 1.00 & 1.00 & 0.83 \\
\hline Wroclaw & 0.95 & 0.99 & 0.99 & 0.90 & 0.87 & 0.93 & 0.88 & 0.93 & 0.85 & 0.95 & 0.98 & 0.99 & 0.94 & 0.99 & 0.87 & 1.00 & 1.00 & 0.83 \\
\hline Zielona Gora & 0.86 & 0.85 & 0.82 & 0.90 & 0.92 & 0.90 & 0.95 & 0.90 & 0.89 & 0.88 & 0.83 & 0.82 & 0.89 & 0.85 & 0.96 & 0.83 & 0.83 & 1.00 \\
\hline
\end{tabular}

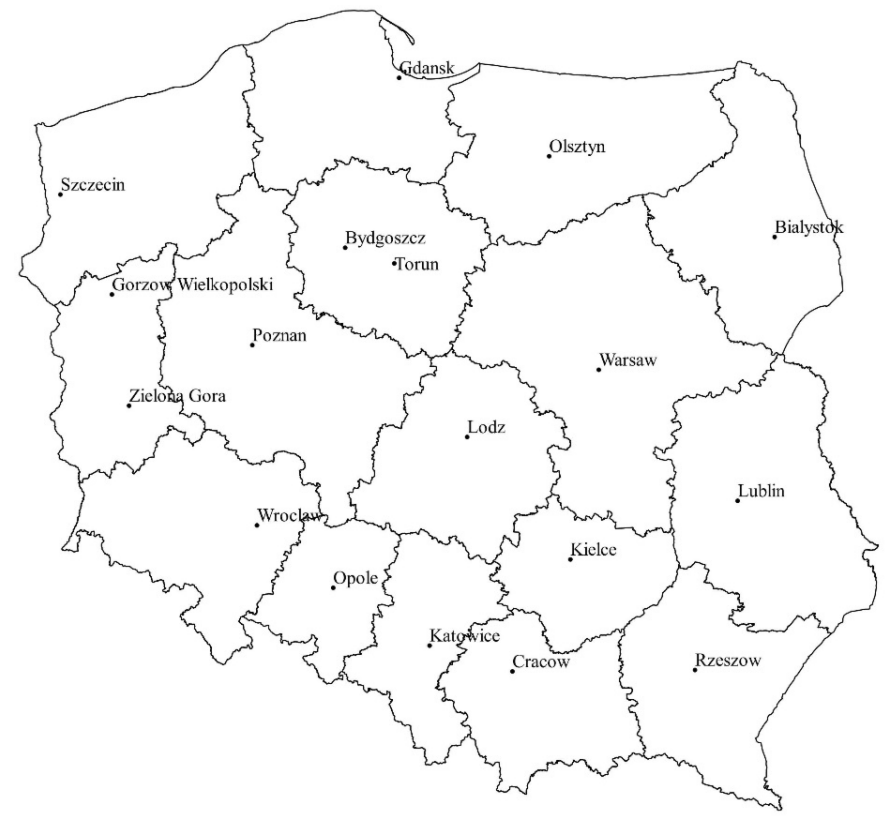

Figure A1. Province capital cities in Poland (source: own research) 


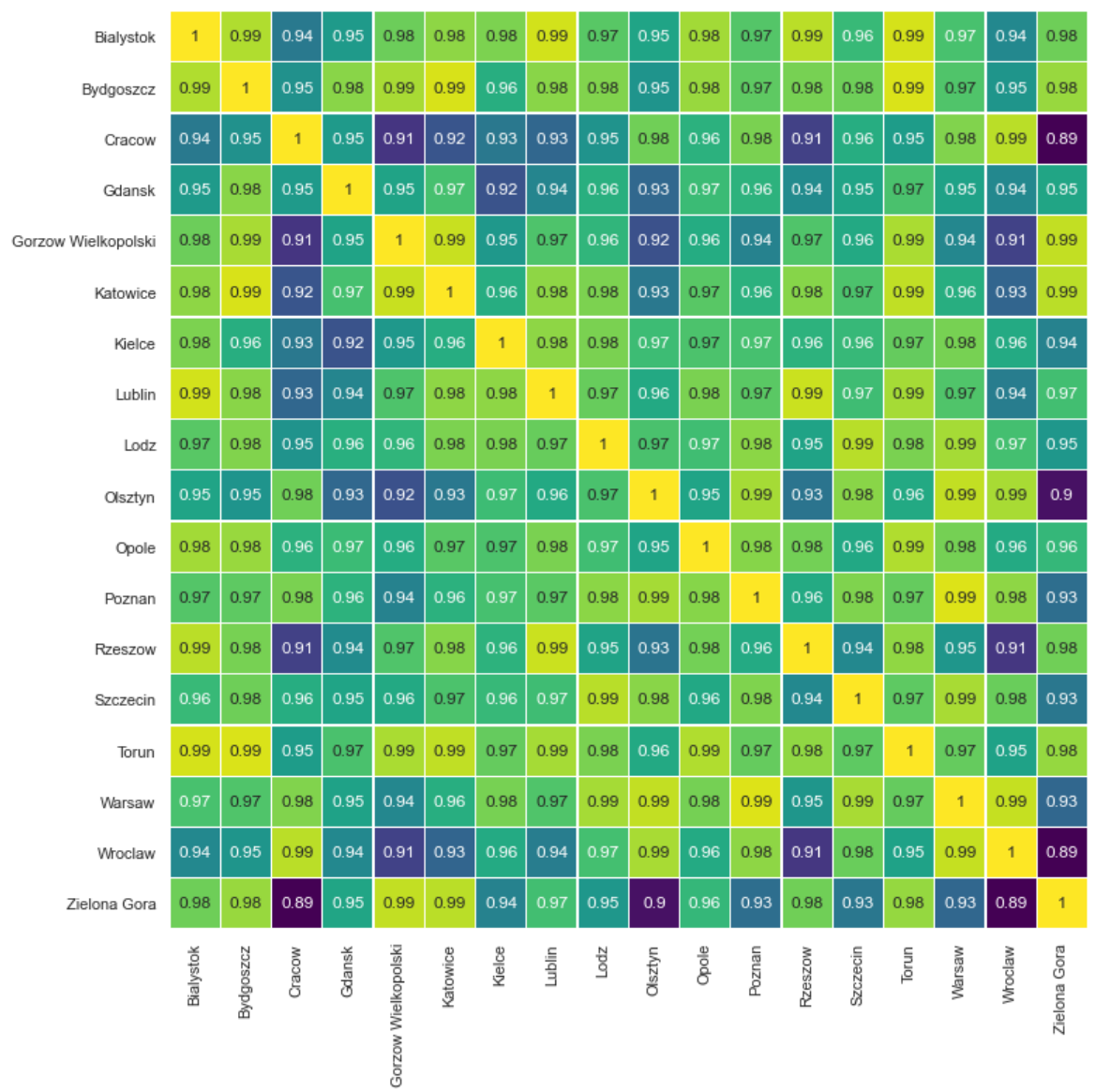

Figure A2. Correlation of housing cycles in provincial capital cities in 2000-2020 (source: own research) 